\title{
Should We Look For Blood Parathormone in Patients with Vertigo?
}

\author{
Vertigo Hastalarında Kanda Parathormon Bakmalı mıyız?
}

\author{
Nevzat Demirbilek, Cenk Evren \\ Medilife Beylikdüzü Hospital, Department of Otorhinolaryngology, Istanbul, Turkey
}

\begin{abstract}
Aim: Though vertigo is a symptom which is defined by an individual as spinning of themselves or an object, it is generally defined by the patients as the sensation of falling, disequilibrium, dizziness and fainting. The main problem on the patients is the determination of the underlying illness. Most of vertigos have peripheral causes and benign paroxysmal positional vertigo takes the first place. It is followed by peripheral and central causes. Patients usually consult the policlinics of Ear, Nose and Throat, internal medicine, neurology in addition to emergency departments with balance disorders. These patients undergo examinations, screening methods, audiology and balance tests and routine blood tests.
\end{abstract}

Material and Method: In this study in which 397 patients who consulted the hospital with complaints of vertigo between 2011 and 2017 evaluated retrospectively.

Results: In ourstudy, first of all peripheral causes and $44.8 \%$ of these were benign paroxysmal positional vertigo. Hyperparathyroidism was detected in 4 (1\%) of the cases in our patient groups that the only complaint was dizziness and there were no other characteristics in the examinations. Parathyroid adenoma was detected in three of them and hyperplasia was detected in the other. In the ones who had adenoma after parathyroidectomy and in the other case after bisphosphonate treatment, both parathormone levels decreased to normal and vertigo complaints totally disappeared.

Conclusion: It is recommended that parathormone values should be taken into account in the blood tests during the process of diagnosis in vertigo patients.

Key words: vertigo; dizziness; hyperparathyroidism

\section{ÖZET}

Amaç: Vertigo kiși tarafından etrafındaki objelerin veya kendisinin döndügü șeklinde ifade edilen bir semptom olmasına karșın, hastalar tarafindan genel olarak dengesizlik, sersemlik, düșme ve baygınlık hissi olarak tanımlanır. Hastalarda asıl sorun altta yatan hastalığın belirlenmesidir. Vertigoların çoğu periferik nedenlidir ve ilk sırada benign paroksimal pozisyonel vertigo yer alır. Bunu diğer

Cenk Evren, Medilife Beylikdüzü Hospital, Department of Otorhinolaryngology, Istanbul 34520,Turkey, Tel.05342105042Email.drcenkevren@yahoo.com Geliş Tarihi: 06.02.2019 • Kabul Taribi: 04.03.2019 periferik ve santral nedenler takip etmektedir. Hastalar denge sorunları nedeniyle akut dönemde çoğunlukla acil poliklinikler haricinde Kulak Burun Boğaz, iç hastalıkları, nöroloji polikliniklerine bașvururlar. Bu hastalara muayene, görüntüleme yöntemleri, odyoloji ve denge testleri ile rutin kan testleri yapılmaktadır.

Materyal ve Metot: Hastanemize 2011-2017 yılları arasında vertigo yakınması ile bașvuran 397 hasta retrospektif olarak değerlendirildi.

Bulgular: Çalıșmamızda, ilk sırada periferik nedenler ve bunların bașında da \%44,8 oranında benign paroxysmal positional vertigo saptanmıștır. Hasta gruplarımızda tek yakınması baș dönmesi olan, diğer muayenelerinde özellik bulunmayan 4 (\%1) olgumuzda hiperparotiroidi saptanmıștır. Bunların üçünde paratiroid adenomu, diğer olguda hiperplazi belirlenmiștir. Adenom saptananlarda paratiroidektomi sonrası, diğer olgumuzda bifosfonat tedavisi sonrası hem parathormon düzeyleri normale inmiș hem de vertigo yakınmaları tamamen kaybolmuștur.

Sonuç: Vertigo hastalarında tanı așamasında kan testlerinde parathormon değerlerine de bakılması tavsiye edilmektedir.

Anahtar kelimeler: baș dönmesi; sersemlik; hiperparatiroidi

\section{Introduction}

Vertigo is either a sensation of motion when there is no motion or an exaggerated sense of motion in response to movement ${ }^{1}$. Dizziness comes in many forms in each age group. In pediatric and adolescent the most common diagnosis is a migraine headache, as frequent causes of disequilibrium in adults is Benign Paroxysmal Positional Vertigo (BPPV) ${ }^{2,3}$. Along with that, a group which is defined as idiopathic vestibulopathy is discussed ${ }^{4}$.

Primary hyperparathyroidism (PHPT) is a disease which occurs as a result of the fact that parathyroid glands overly release it and which generally appears with hypercalcemia and symptoms related to it. The recent prevalence of PHPT is approximately between $0.25 \%$ and $0.66 \%$ of the population. Women are more affected than men with a rate of $3: 1$. Incidence increases as the 
age go up, and it has a dramatic increase after the age of 505 . The most frequent cause (\% 80-85) for PHPT is parathyroid adenoma ${ }^{5-8}$. The patients of hyperparathyroidism frequently consult doctors with complaints of bone pain, renal calculus, constipation, fatigue, drinking too much water, need to urinate and broken bones stories $^{9,10}$. Asymptomatic $\mathrm{pHPT}$ has a prevalence of between $72.7 \%$ and $95 \%$, and it becomes the dominant phenotype of pHPT in modern western societies ${ }^{11,12}$. In asymptomatic hyperparathyroidism patients, serum calcium may be slightly high; PTH may be 1.5-2 times higher than average or may be close to the upper limit of normal as a result of being incompatible with calcium level. When retrospectively questioned, symptoms such as depression, fatigue, and lethargy were detected with a maximum rate of $80 \%$ in the patients ${ }^{13,14}$.

In this study, besides routine biochemical examinations, PTH levels were also checked in the patients who consulted the hospital with complaints of vertigo. Mainly the results of vertigo patients that etiology was not detected were presented with literature knowledge.

\section{Material and Method}

In this study in which 578 patients who consulted the hospital with complaints of vertigo between 2011 and 2017 evaluated retrospectively. One hundred eightyone patients of whom neurological examinations were not completed, who did not have blood results and who were under 18 years old were not included in the study. The Anamnesis, applications and follow-ups, systemic and neurologic examinations, the information of age, sex and biography, the examinations carried out for diagnosis (laboratory results, neuroimaging, the screening of the vascular structure of neck, vestibular and audiological examinations) were recorded from the information obtained from the files. The study protocol was approved by the ethical board of the hospital $(2019 / 02)$.

From biographic information of the patients, cerebrovascular disease, hypertension, diabetes mellitus, dyslipidemia, chronic obstructive pulmonary disease, atrial fibrillation, migraine, previous cerebrovascular disease, a disorder of thyroid, Parkinson disease, epilepsy, psychiatric story and the story of malignancy were taken under review. Sex and age distributions according to the main symptoms of the patients were determined. All the patients were divided into four groups of peripheral, central, psychogenic and metabolic concerning diagnosis information.
Routine ENT and head and neck examination, Head Thrust Test, dynamic positional tests (Dix-Hallpike and Roll), fistula test, Romberg test, Post-pointing test, walking test (Babinski-Weil) and Fukuda (Unterberger) test were applied on all of the patients.

As laboratory examinations, complete blood count, FT3, FT4, TSH, preprandial blood glucose, urea, creatinine, cholesterol, vitamin B12, vitamin $\mathrm{D}, \mathrm{PTH}$ and blood calcium tests were carried out. Blood samples were taken at the hours between 08.00 and 09.00 after a night of fasting. Serum calcium and phosphor levels were measured via AU 2700 analyzer (Beckman Coulter, Tokyo, Japan) with the colorimetric method. The concentrations of vitamin D and PTH were measured via Coulter UniCel DxI 600 immunoanalyser (Beckman Coulter, CA, USA).

Neck ultrasonography and $99 \mathrm{mTc}-\mathrm{MIBI}$ parathyroid scintigraphy was carried out in order to diagnose and localize the pathologic gland on the patients on whom PHPT was detected. The existence of bone pathology which was caused by hyperparathyroidism was investigated via direct bone radiographic. Selective parathyroidectomy operation was carried out on three patients who possessed adenoma (Figure 1). Bisphosphonate treatment was provided to the case that was thought to be hyperplasia.

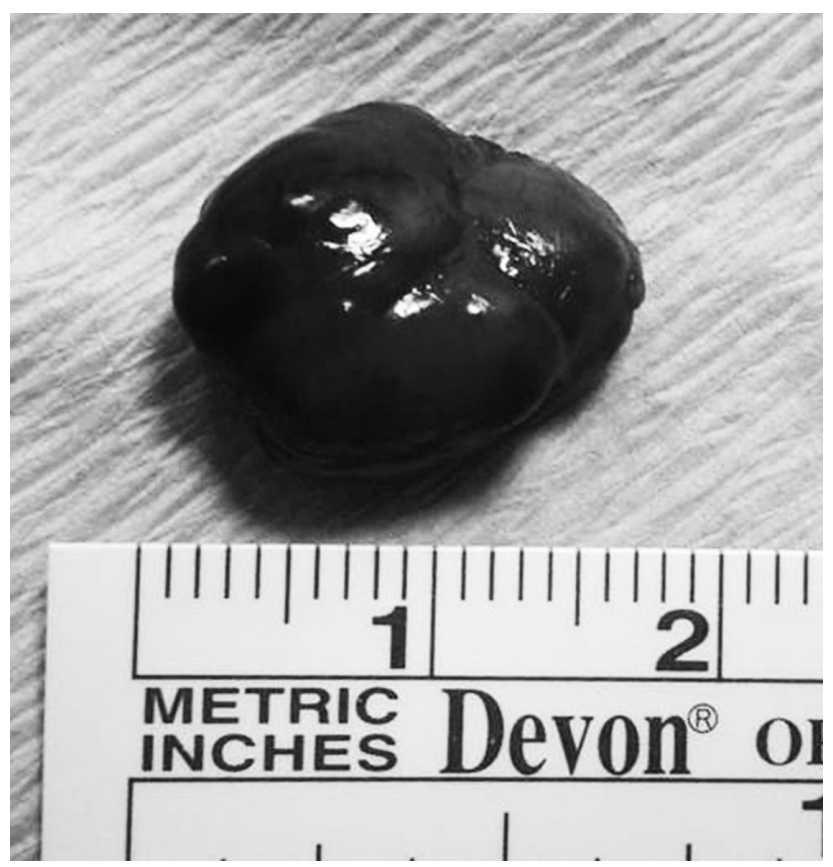

Figure 1. Gross image of parathyroid adenoma. 
The sample size was not calculated for the present study due to the design of the present study, and all patients who treated at our clinic between 2011-2017 were included in the present study. Statistical analyses were carried out on IBM SPSS for Windows Version 22.0 package software program. Numeric variables were summarized with average \pm standard deviation while categorical variables were summarized with number and percent. The fact that whether there were any differences in terms of categorical variables was investigated via chi-square test or Fisher exact test. The significance level was taken as $\mathrm{p}<0.05$.

\section{Results}

In this study, 397 patients (between the ages of 18 and 82 ) were evaluated. 251 (63.2\%) of the patients were female; $146(36.8 \%)$ of them were male. The average age of the patients was $59.9 \pm 18.2$. The patients were divided into four groups as peripheral, central, psychogenic and metabolic depending on their diagnosis. There were $210(53 \%)$ patients in the peripheral group, 98 patients $(24.6 \%)$ in central group, 56 patients $(14.1 \%)$ in the psychogenic group and 33 patients $(8.3 \%)$ in the metabolic group.

Age distribution of the patients according to their diagnosis related groups was determined. 144 (68.6\%) of the peripheral group were female while 66 (31.4\%) of them were male, $47(47.9 \%)$ of the central group were female while 51 (52.1\%) of them were male, 42 (75\%) of the psychogenic group were female while 14 (25\%) of them were male, $18(54.5 \%)$ of the metabolic group were female while 15 (45.5\%) of them were male. It was observed in the age distribution according to diagnosis-related groups that the women ratio was statistically significantly higher in the psychogenic group $(\mathrm{p}<0.001)$. The consultation time of the patients in the central group was statistically significantly different from the other groups $(p<0.001)$. The patients in the central group had shorter consultation times.

Age distribution of the patients according to their diagnosis related groups was determined. The average age of the peripheral group was $59.1( \pm 17.7)$, the average age of the central group was $62.6( \pm 18.1)$, the average age of the psychogenic group was $50.7( \pm 16.1)$ and the average age of the metabolic group was $61.4( \pm 18.4)$. It was observed in the age distribution according to their diagnosis related groups that the average age in the psychogenic group was statistically significantly lower than the other groups $(p<0.001)$. Clinical and demographic data of the patients are shown in Table 1.

In this study, the distribution of 210 (53\%) patients who were in the peripheral group according to diagnosis-related groups (Table 2). In 178 (44.8\%) of these patients, BBPV was detected as the cause, and in 153 of them, posterior canal involvement was detected while lateral canal involvement was detected in 25 of them. 21 of them $(5.4 \%)$ were diagnosed with Meniere disease, 4 of them $(1 \%)$ were diagnosed with vestibular neuritis, 4 of them (1\%) were diagnosed with the usage of vestibulotoxic drugs, 2 of them (0.5\%) were diagnosed with lateral semicircular canal fistula (LMCF) due to chronic otitis, 1 of the patients $(0.3 \%)$ was diagnosed with superior semicircular canal dehiscence syndrome (SSCD). The patients who were diagnosed with BBPV were treated with canalith repositioning maneuvers (Modified Epley, Barbeque). The treatments of dieting, betahistine HCI and transtympanic steroid treatments were carried on the patients who were diagnosed with

Table 1. Clinical and demographic data of the patients

\begin{tabular}{lcccc}
\hline & Peripheral & Central & Psychogenic & Metabolic \\
\hline Number of Cases & 210 & 98 & 56 & 33 \\
Average age & $59.1 \pm 17.7$ & $62.6 \pm 18.1$ & $50.7 \pm 16.1^{\star}$ & $61.4 \pm 18.4$ \\
Vertigo presentation duration (days) & $6.7 \pm 9.8$ & $3.5 \pm 6.3^{\star \star}$ & $9.8 \pm 12.3$ & $6.2 \pm 10.3$ \\
Sex & & 51 & 14 & 15 \\
Male & 66 & 47 & $42^{\star \star \star}$ & 18 \\
Female & 144 & & & \\
First vertigo attack & $60 \%$ & $72 \%$ & $65 \%$ & $80 \%$ \\
\hline
\end{tabular}

${ }^{*} p<0.001,{ }^{* \star} p<0.001,{ }^{* \star \star} p<0.001$, Chi-square test/Fisher exact test. 
Table 2. The causes of peripheral vertigo

\begin{tabular}{lcc}
\hline & Number & All Cases (\%) \\
\hline BPPV & 178 & 44.8 \\
Meniere Disease & 21 & 5.4 \\
Vestibular Neuronitis & 4 & 1.0 \\
Vestibulotoxicity & 4 & 1.0 \\
LSCF & 2 & 0.5 \\
SSCD & 1 & 0.3 \\
\hline
\end{tabular}

BPPV, benign paroxysmal positional vertigo; LSCF, lateral semicircular canal fistula; SSCD, superior semicircular canal dehiscence syndrome.
Table 3. The causes of central vertigo

\begin{tabular}{lcc}
\hline & Number & All Cases (\%) \\
\hline Migrainous Vertigo & 33 & 8.4 \\
VBI & 27 & 6.8 \\
Ischemic Stroke & 14 & 3.5 \\
TIA & 9 & 2.3 \\
SOL & 6 & 1.5 \\
Parkinson & 3 & 0.7 \\
Epilepsy & 3 & 0.7 \\
Demyelinating Disease & 3 & 0.7 \\
\hline VBI, vertebrobasilar insufficiency; TIA, transient ischemic attack; SOL, space occupying lesion.
\end{tabular}

detected. Selective parathyroidectomy was applied to the patients who possessed adenoma. On the postoperative first day, PTH levels of all patients returned to normal, and in the next one-week period all their complaints disappeared. The case in which hyperplasia was detected was taken under bisphosphonate treatment, PTH levels returned to normal in a short time, and the complaints were gone. It was found in PHPT cases in which adenoma was detected that in the first case PTH level was $137 \mathrm{pg} / \mathrm{mL}$, in the second case it was $125 \mathrm{pg} / \mathrm{mL}$, in the third case it was $85 \mathrm{pg} / \mathrm{mL}$, in the fourth case it was $128 \mathrm{pg} / \mathrm{mL}$. Post-treatment PTH levels were valued as $12 \mathrm{pg} / \mathrm{mL}, 10 \mathrm{pg} / \mathrm{mL}, 5 \mathrm{pg} / \mathrm{mL}$ and $8 \mathrm{pg} / \mathrm{mL}$ respectively. The difference between the PTH levels of pre-treatment and post-treatment was statistically significant $(\mathrm{p}<0.05)$.

\section{Discussion}

Vertigo and balance disorders are significant health problems in every country in the world. Particularly, more than $30 \%$ of the people who are over 60 experience dizziness complaints in a period of their lives ${ }^{3}$. About $5 \%$ of primary clinic consultations consist of dizziness. This complaint can be limited within four groups concerning patient history: Vertigo, disequilibrium, presyncope, and lightheadedness (nonspecific dizziness). The leading causes of vertigo are benign proximal positional vertigo, Meniere disease, vestibular neuritis, and labyrinthitis. Presyncope mostly occurs as an adverse effect of medications; however, the consultation can be with a diagnosis of Parkinson disease and diabetic neuropathy disequilibrium. Psychiatric disorders such as depression, anxiety, and hyperventilation mostly define lightheadedness ${ }^{15,16}$. 
Etiologies migraine, migraine, paroxysmal vertigo, psychogenic, viral infections, chronic daily headache, trauma, and postural orthostatic tachycardia syndrome may be frequently seen in adolescence ${ }^{2}$. Dizziness caused by Peripheral is the most frequent complaint in middle-aged and older adults. Among all dizziness types in various studies, BPPV takes the first place with rates of $25-50 \%$, and it was followed by Meniere syndrome, vestibular neuronitis, vestibular migraine, and psychogenic dizziness ${ }^{2,3,15,19-21}$. It was determined in this study that the most frequent cause of dizziness was BPPV in line with the literature. Furthermore, the psychogenic group was statistically more significant than the other groups, and it has consisted of predominantly young and female patients.

The series consisted of the patients who had chronic vertigo complaints. Age groups were in such a wide range as 18-82 years old, and most of them were the patients who were on the fifth and sixth decade. Peripheral causes were seen as the first cause with the rate of $53 \%$ in the cases investigated. The most frequent cause was BPPV with a rate of $44.8 \%$, and it was followed by central dizziness with a rate of $26.6 \%$. The total percentage of psychogenic (14.1\%) and metabolic (8.3\%) groups was as high as $24.4 \%$ in this study. When their symptomatology was investigated, it is remarkable that most of them were not specific and there were not significant characteristics in the findings of their examination. The fact that the patients who consulted hospitals with vertigo complaint are treated symptomatically not only in emergency clinics but also in other clinics caused the perception of "vertigo is untreatable" by the patients ${ }^{3,15,16}$. Particularly to the patients who did not possess any symptoms except balance disorder, drug use and quitting taking drugs were asked, neurologic, psychiatric and endocrinological consultations were carried out. Psychiatric and metabolic causes were determined in these cases which were defined as idiopathic vertigo. In the routine examinations which were recommended in this study, hemogram, glucose, thyroid, and lipid metabolism examinations are carried out, and folic acid, vitamin B12, vitamin D, and serum electrolytes levels are measured ${ }^{16,19,20}$. In this study, PTH levels of the cases were investigated in addition to these items.

Vitamin B12 deficiency affects multiple systems, and sequelae vary in severity from mild fatigue to severe neurologic impairment. Neurologic manifestations are caused by progressive demyelination and can include peripheral neuropathy, areflexia and the loss of proprioception and vibratory sense ${ }^{22}$. Hunt et al. reported asymptomatic vitamin $\mathrm{B} 12$ deficiencies with the rates which increase by age in several societies ${ }^{23}$. In this study, vitamin B12 deficiency with the rate of $2.5 \%$ was detected on the patients who consulted with the complaint of a balance disorder.

Even though there are several studies carried out on the links between hypercalcemia, vitamin D deficiency and disequilibrium, gait disorder and BPPV; there is no relationship reported between PHPT which continue with normal calcium and phosphates levels and vertigo $^{17,18}$. PHPT is a clinical syndrome which leads to hypercalcemia (occasionally normocalcemia) and hypophosphatemia caused by excessive PHT release and continues with the diagnosis depending on this fact. It is generally defined as the disease of stones, bones, abdominal cavity, and psychogenic complaints. Besides typical symptoms, gait disorder, disequilibrium, and psychiatric disorders, as well as nonspecific symptoms such as cervical and mediastinal hemorrhaging which occurs due to spontaneous laceration of parathyroid adenoma, may appear ${ }^{6,24-28}$.

Recently, primary HPT means the HPT table on which there are no complaints of skeletal, renal and neuromuscular systems ${ }^{7-10}$. Despite being asymptomatic during preoperative evaluations, patients often report post-operative retrospective amelioration of unreported preoperative sign and symptom of hyperparathyroidism $^{29}$. Frequent non-specific symptoms in the general population might be partly responsible for that, as they often make the diagnosis difficult and interdisciplinary ${ }^{30}$.

PTH levels which increased with normal serum calcium are less occasionally seen in the cases of asymptomatic hyperparathyroidism. The diagnosis of this case is provided with the fact that there are no causes to increase secondary parathormone and the level of serum 25-hydroxyvitamin D remains normal level. In the countries where vitamin $\mathrm{D}$ deficiency is widely seen, the occurrence frequency of normocalcemic hyperparathyroidism increases depending on the fact that vitamin $\mathrm{D}$ deficiency masks the increase in the serum calcium concentration which is linked to $\mathrm{PHPT}^{14}$. The fact that most of the dizziness does not have any typical symptomatology and vitamin $\mathrm{D}$ deficiency prevalence is high in Turkey lowered the PHPT probability. As a result of this fact, PTH levels of the patients who consulted the hospital with vertigo complaint were 
checked routinely. In the ones who had high PTH, the existence of parathyroid adenoma was investigated. In the ones in whom adenoma was detected, the adenoma was surgically removed. In another patient who did not possess adenoma and diagnosed with hyperplasia, symptoms dramatically disappeared with bisphosphonate treatment. These two cases strengthened the hypothesis of this study.

The relationship between hyperparathyroidism and vertigo is not clear. Wu et al. and Guler et al. remarked that the relationship between BPPV and hypercalcemia and asserted that the calcium increase in canalith might be caused by this ${ }^{17,18}$. Vosnakidis et al. detected hypercalcemia and HPT as the cause of atrioventricular block on a patient who consulted with the complaints of dizziness and headache. They related this fact to calcium cumulating in the heart of the patient ${ }^{31}$. It is thought that, in some of HPT cases, the tables such as metabolic syndrome, pancreatitis, cardiovascular diseases, and autoimmune gastritis may be related to asymptomatic calcium depositions on these organs10. Lundberg et al. stated in their experimental studies that calcium depositions may occur on membranous labyrinth endolymph which is deficient in calcium ions ${ }^{32}$.

As a conclusion, it is recommended that in the patients who consult with complaints of balance disorder, all the symptoms which are nonspecifically evaluated in their history should be evaluated carefully and algorithms regarding the etiology should be constituted. It is also recommended that parathormone values in blood should be investigated as hyperparathyroidism was detected as a cause of vertigo with a rate of $1 \%$ in this study.

\section{References}

1. Lustig LR, Schindler JS. Ear, Nose and Throat Disorders. In: Papadakis, editors. Current Medial Diagnosis and Treatment. New York; Mc Graw Hill Education 2014 193-234.

2. Taylor J, Goodkin HP. Dizziness and vertigo in the adolescent. Otolaryngol. Clin N Am 2011;2:309-23.

3. Shepard N T, Solomon D. Functional Operation of the Balance System in Daily Activities. The Otolaryngologic Clinics Of North America 2000;33:455-69.

4. Uneri A, Polat $\mathrm{S}$. Vertigo, dizziness and imbalance in the elderly. Laryngol Otol 2008;122:466-9.

5. Yeh MW, Ituarte PH, Zhou HC, Nishimoto S, Liu IL, Harari A et al. Incidence and prevalence of primary hyperparathyroidism in a racially mixed population. J Clin Endocrinol Metab 2013;98:1122-9.
6. Zha C, Wang X, Wei H, Ma G. Parathyroid adenoma causing a spontaneous cervical and mediastinal massive hematoma. Int $\mathrm{J}$ Clin Exp Med 2015;8:21826-9.

7. Yao XA, Wei BJ, Jiang T, Chang H. The characteristics of clinical changes in primary hyperparathyroidism in Chinese patients. $\mathrm{J}$ Bone Miner Metab 2018;1:22-3.

8. Adami S, Marcocci C, Gatti D. Epidemiology of primary hyperparathyroidism in Europe. J Bone Miner Res 2002; 17:18-23.

9. Parmar G, Chadha M. The Changing Face of Primary Hyperparathyroidism. Indian $\mathrm{J}$ Endocrinol Metab 2018;3:299-300.

10. Jodkowska A, Tupikowski K, B, Szymczak L, BohdanowiczPawlak A, Bolanowski M, Bednarek-Tupikowska G. Interdisciplinary Aspects of Primary Hyperparathyroidism: Symptomatology in a Series of 100 Cases. Adv Clin Exp Med 2016;2:285-93.

11. Vignali E, Viccica G, Diacinti D, Cetani F, Cianferotti L, Ambrogini E et al. Morphometric vertebral fractures in postmenopausal women with primary hyperparathyroidism. J Clin Endocrinol Metab 2009;94:2306-12.

12. Wermers RA, Khosla S, Atkinson EJ, Achenbach SJ, Oberg AL, Grant CS et al. Incidence of primary hyperparathyroidism in Rochester, Minnesota, 1993-2001: an update on the changing epidemiology of the disease. J Bone Miner Res 2006;21:171-7.

13. Bilezikian JP, Potts JT Jr. Asymptomatic primary hyperparathyroidism: new issues and new questions-bridging the past with the future. J Bone Miner Res 2002;17:57-67.

14. Bilezikian JP, Silverberg SJ. Clinical practice. Asymptomatic primary hyperparathyroidism. N Engl J Med 2004;17:1746-51.

15. Jung I, Kim JS. Approach to dizziness in the emergency department. Clin Exp Emerg Med 2015;2:75-88.

16. Post RE, Dickerson LM. Dizziness: A Diagnostic Approach Am Fam Physician 2010;82:361-8.

17. Wu Y, Fan Z, Jin H Guan Q, Zhou M, Lu X, Li Let al. Assessment of Bone Metabolism in Male Patients with Benign Paroxysmal Positional Vertigo. Front Neurol 2018;9:742.

18. Guler I, Baklacı D, Kuzucu I, Kum RO, Ozcan M. Benign Paroksismal Pozisyonel Vertigolu Hastalarda Serum 25-hidroksi vitamin D Düzeylerinde Azalma. KBB-Forum 2018;17:35-9.

19. Voelker CCJ, Goebel JA. Clinical Evaluation of the Patient with Vertigo. In: Johnson JT and Rosen CA, editors. Bailey's Head \&Neck Surgery Otolaryngology Vol 2. Phlidelphia, Lippincott Williams\&Wilkins 2014:2673-700.

20. Wipperman J. Dizziness and vertigo. Prim Care 2014;41:115-31.

21. Neuhauser HK. The epidemiology of dizziness and vertigo. Handb Clin Neurol 2016;137:67-82.

22. Langan RC, Goodbred AJ. Vitamin B12 Deficiency: Recognition and Management. Am Fam Physician 2017;96:384-89.

23. Hunt A, Harrington D, Robinson S. Vitamin B12 deficiency. BMJ 2014;349:5226.

24. Ugalde I, Bello Segura M, Oneto S, Ciment A. The forgotten electrolyte, when hypercalcaemia manifest as gait instability and altered mental status. BMJ Case Rep 2018;5:224089. 
25. Corbetta S, Mantovani G, Spada A. Metabolic Syndrome in Parathyroid Diseases. Front Horm Res 2018;49:67-84.

26. Ota K, Koseki S, Ikegami K, Onishi I, Tomimitsu H, Shintani S. Dropped head syndrome as first manifestation of primary hyperparathyroid myopathy. Rinsho Shinkeigaku 2018;58:193-7.

27. Grubina R, Klocke D K 47-Year-Old Woman With Dizziness, Weakness, and Confusion 2. Mayo Clin Proc 2011;86:1-4.

28. Parks KA, Parks CG, Onwuameze OE, Shrestha S. Psychiatric Complications of Primary Hyperparathyroidism and Mild Hypercalcemia. Am J Psychiatry 2017;1:620-2.

29. Lendel I, Horwith M. An update from the latest workshop on asymptomatic primary hyperparathyroidism. Otolaryngol. Clin N Am 2004;37:737-51
30. Smith JA, Stack BC. Pathophysiology of the parathyroid glands. In: Terris DJ, Gourin CG, editors. Thyroid and Parathyroid Diseases Medical and Surgical Management. New York, Thieme 2009:184-197.

31. Vosnakidis A, Polymeropoulos K, Zarogoulidis P, Zarifis I. Atrioventricular nodal dysfunction secondary to hyperparathyroidism. Journal of Thoracic Disease, 2013;5:90-2.

32. Lundberg YW, Zhao X, Yamoah EN. Assembly of the otoconia complex to the macular sensory epithelium of the vestibule. Brain Res 2006 May 26;1091:47-8. 